\title{
Pengaruh Teknologi Informasi Terhadap Akhlak Siswa Kelas V SDN 147 Pekanbaru
}

\author{
Armia $^{1}$, Muhammad Sahlan $^{2}$ \\ ${ }^{1}$ Program Magister Pendidikan Madrasah Ibtidaiyah, Universitas Islam Negeri Sultan Syarief \\ Kasim Riau \\ ${ }^{2}$ Magister Universitas Kebangsaan Malaysia \\ e-mail: armiamia1989@gmail.com
}

\begin{abstract}
Education of behavior represent especial problems which always become human being challenge in as long as history civilization of nations in]world. history indicating that a[n nation will be sturdy if its sturdy behavior conversely an nation will collapse if its behavior destroy

This research aim to to know what is there is influence which are positive among/between Penggunaaan Information Technology with student behavior of SD Country 147 Pekanbaru. To obtain;get required by data is writer use three data collecting technique that is: (1) Enquette, (2) Documentation Population in this research is Class student of V in SD Country 147 Town of Pekanbaru amounting to 139 student people. Because to the number of population, hence writer take sampel that is $25 \%$ from existing population with technique of Proposional Random Sampling. Become sampel of this research that is counted 35 student people. In quantitative data processing, writer of technique cave analyse quantitative approach with technique cave analyse linear regresi with Smallest Square method by using computer program of SPSS Windows version for 18.0

Conclusion that pursuant to reached persetase in this research can know that there is influence which is signifikan among/between Usage of Information Technology to student behavior. Influence storey;level among/between both variable reside in at high or strong category with reng $(0,700-0,900)$, that is equal to 0,794 . While coefficient of determinasi ( Square R) is 0,631 , Contribution information technology to student behavior equal to $0,631 \times 100=63,1 \%$ and rest influenced by other factor. this situation indicate that active progressively student in using Information Technology, hence student behavior progressively shift from behavior of Islami.
\end{abstract}

Kata kunci: Information Technology, student morals

\section{PENDAHULUAN}

Pendidikan akhlak merupakan permasalahan utama yang selalu menjadi tantangan manusia dalam sepanjang sejarah peradaban bangsa-bangsa di dunia.sejarah yang menunjukkan bahwa suatu bangsa akan kokoh apabila akhlaknya kokoh dan sebaliknya 
suatu bangsa akan runtuh apabila akhlaknya rusak. Akhlak merupakan dasar yang utama dalam pembentukan kepribadian manusia seutuhnya. Pendidikan yang mengarah pada terbentuknya kepribadian berakhlak merupakan hal yang pertama yang harus dilakukan, sebab akan melandasi kestabilan kepribadian secara keseluruhan. Akhlak adalah Ilmu yang mengkaji suatu perbuatan yang dilakukan oleh manusia dalam keadaan sadar, kemauan sendiri, tidak terpakasa dan sungguh-sungguh atau sebenarnya bukan pura-pura.perbuatan tersebut diberi nilai pada baik atau buruk.

Abuddin Nata mengatakan bahwa akhlak yaitu membahas perbuatan manusia yang selanjutnya perbuatan tersebut ditentukan baik atau buruknya. Jadi Ilmu akhlak berfungsi memberikan panduan kepada manusai agar mampu menilai dan menetukan suatu perbuatan baik atau buruk. Manusia dizaman modern ini dihadapkan pada masalah moral dan akhlak yang cukup serius, yang kalau dibiarakan akan menghancurkan masa depan bangsa yang bersangkutan. Praktek hidup yang menyimpang dan penyalahgunaan kesempatan bisa mengakibtakan kerugian pada orang lain.

Pesatnya perkembangan Ilmu Pengetahuan dan Teknologi (IPTEK), seperti Internet di era globalisai bisa menyebabakan bergesernya nilai-nilai akhlak anak bangsa karena perkembangan iptek ibarat pisau ditangan penjahat.Teknologi Internet disamping menawarkan berbagai kemudahan dan kenyamanan hidup, juga membuka peluang untuk melakukan kejahatan yang lebih canggih, jika penggunaan Internet disalahgunakan. Ketika teknologi Internet berkembang pada zaman sekarang, maka anak-anak harus dibekali dengan pendidikan akhlak.Karena kemajuan teknologi era globalisasi ini erat kaitannya dengan perubahan sikap.

Pengaruh dari arus globalisasi ini menyentuh hampir semua bidang kehidupan, mulai dari yang bersifat material, yang bersifat keilmuan, yang bersifat sosial dan yang bersifat moral dan etis seperti pergaulan bebas, lemahanya disiplin moral, longgarnya norma susila dal lain-lain. Upaya utama yang harus dilakukan dalam mengembangkan pengetahuan dan teknologi ini adalah melalui pendidikan, yang menekankan pada penguasaan ilmu pengetahuan dan teknologi yang dijiwai oleh semangat kebangsaan serta dilandasi oleh keteguhan iman dan taqwa (IMTAQ).

Sebagaimana dikemukakan Wardiman Djojonegoro dalam Muhammad Tholhah Hasan manusia yang berkualitas adalah manusia yang minimal memilki kompetensi dalam ilmu pengetahuan dan teknologi, serta kompetensi dalam keimanan dan ketaqwaan kepada Allah swt. Kompetensi Imtaq amat penting karena tanpa dibingkai oleh iman dan taqwa, maka kompetensi Iptek akan menjadi kurang artinya, bahkan dikhawatirkan akan liar dan tidak terkendali lagi, yang mewujudkan diri dalam bentuk terjadinya erosi nilai-nilai moral dan bergesernya nilai-nilai akhlak.

Teknologi mengubah masyarakat, kepercayaan, adat istiadat, dan organisasinya, sehingga disesuaikan dengan tuntunan dan kepentinagn teknologi. Begitu besarnya pengaruh teknologi, akibatnya ialah teknologi memisahkan manusia dari tujuan karyanya dan dengan demikian menimbulkan alienasi terhadap masyarakat dimana ia hidup, teknologi menjadi tidak compatible (tidak runtun dan harmanonis) dengan nilai-nilai kemanusiaan.

Dalam menghadapi situasi demikian itulah orang mulai sadar tentang datangnya krisis kehidupan dewasa ini, bagi Indonesia, tantangan ini bukan saja terbatas pada bagaimana menghindari kecendrungan-kecendrungan dasar perkembangan ilmu pengetahuan dan teknologi, melainkan juga bagaimana membentuk struktur sosial yang dapat menghadapinya. Hal ini bukan saja menjadi tanggung jawab pendidikan nasional, tetapi juga agama dan budaya.

Ilmu akhlak atau akhlak yang mulia berguna dalam mengarahkan dan mewarnai berbagai aktivitas kehidupan manusia di segala bidang. Seseorang yang memilki ilmu pengetahuan dan teknologi yang maju yang disertai dengan akhlak yang mulia, niscya ilmu pengetahuan dan teknologi modern yang ia miliki itu akan dimanfaatkan sebaik-baiknya untuk kebaikan hidup 
manusia. Namun sebaliknya orang yang memilliki ilmu pengetahuan dan teknologi modern namun tidak disertai dengan akhlak yang mulia, maka semuanya itu akan disalahagunakan yang akibatnya akan menimbulkan bencana dimuka bumi.

Salah satu fenomena yang sekarang sedang berkembang kita hadapi adalah menipisnya akhlak dan moral.Dan hal itu terjadi hampir disemua lapisan masyarakat terutama pada generasi muda sekarang karena perubahan sikap lebih muda terjadi di kalanagan generasi muda dibandingakn generasi tua, bahkan tidak tertutup kemungkinan anak-anak sekolah dasar khususnya.

Dengan pesatnya kemajuan teknologi komunikasi dan informasi, kadang-kadang tontonan yang berupa gambar-gambar porno akan memberikan rangsangan seks bagi anak-anak remaja. Maka hal itu akan berbahaya sebab bisa menghalangi mereka untuk beramal sholeh.

Berdasarkan uraian-uraian di atas dapat dijelaskan bahwa kemajuan Teknologi Informasi dan Komunikasi sebetulnya sangat penting bagi siswa di sekolah dasar.Kemajuan Teknologi Informasi dan Komunikasi hendaknya dapat memberikan pengaruh positif terhadap akhlak siswa sehingga dapat meningkatkan intelektualitasnya.

Berdasarkan hasil pengamatan dan wawancara dengan siswa dan wakil kepala sekolah SDN 147 Pekanbaru, dijumpai fenomena-fenomena antara lain:

1. Adanya sebagian siswa bisa menggunakan Teknologi Informasi (Interenet), namun Akhlaknya mencerminkan akhlak yang mulia, mungkin saja hal ini disebabkan oleh pengetahuan agamanya yang kuat atau lingkungan atau juga karena didikan Orangtuanya. Sedangkan siswa yang kurang atau tidak bisa menggunakan Teknologi Informasi (Internet), namun mereka memilki akhlaknya jelek dan tidak terpuji. Mungkin saja hal ini disebabkan oleh pergaulan dengan temantemannya atau lingkungannya.

2. Dilihat dari akhlak siswa, sangat banyak siswa yang sudah pandai berpacaran, berpergian dengan teman lawan jenisnya yang bukan mahram, mengucapkan kata-kata cinta, dan sering mendengarkan lagu-lagu orang dewasa.

Berdasarkan gejala-gejala tersebut di atas, ada kesenjangan antara adanya Iptek dengan akhlak siswa.Untuk menelaah lebih lanjut tentang keadaan tersebut, maka peneliti merasa perlu untuk mengetahui secara mendalam sejauh mana pengaruh antara Teknologi Informasi dengan akhlak siswa maka peneliti menetapkan judul dengan judul."PENGARUH TEKNOLOGI INFORMASI TERHADAP AKHLAK SISWA KELAS V SDN 147PEKANBARU KECAMATAN TAMPAN".

Alasan saya memilih judul ini, peneliti ingin mengetahui lebih lanjut serta membuktikan melalui penelitian sejauh mana pengaruh Teknologi Informasi dengan akhlak siswa terutama di kalangan siswa SD.

"Karena berangkat dari pada teori yang dikemukan oleh Muhammad Tholhah Hasan, Teknologi mengubah masyarakat, kepercayaan, adat istiadat, dan organisasinya, sehingga disesuaikan dengan tuntunan dan kepentinagn teknologi. Begitu besarnya pengaruh teknologi, akibatnya ialah teknologi memisahkan manusia dari tujuan karyanya dan dengan demikian menimbulkan alienasi terhadap masyarakat dimana ia hidup, teknologi menjadi tidak compatible (tidak runtun dan harmanonis) dengan nilai-nilai kemanusiaan.

Karena telah kita ketahui bersama bahwa dizaman era globalisasi ini banyak hal yang telah terjadi diakibtkan oleh faktor Teknologi Informasi terutama dalam bidang pendidikan akhlak.Maka tidak tertutup kemungkinan Teknologi Informasi (Internet) telah mempengaruhi nilai-nilai akhlak generasi muda. 


\section{METODOLOGI}

Penelitian ini dilaksanakan di sekolah SDN 147 Pekanbaru di kelas V pada taggal 1 Maret 2013 samapai tanggal 2 April 2013. Subjek dalam penelitian ini adalah siswa SDN 147 Pekanbaru kelas V. Sedangkan objek dalam penelitian adalah "Pengaruh Teknologi Informasi terhadap Akhlak siswa SDN 147 Pekanbaru Kecamatan Tampan”.

Populasi dalam penelitian ini adalah seluruh siswa SDN 147 Pekanbaru Kecamatan Tampan, mengingat populasi yang diteliti dalam jumlah yang besar maka peneliti hanya meneliti siswa kelas V SDN, yang berjumlah 139 orang siswa. Karena banyaknya populasi, maka penulis mengambil sampel yaitu $25 \%$ dari populasi yang ada dengan teknik Proposional Random Sampling. Jadi sampel dari penelitian ini yaitu sebanyak 35 orang siswa.

Adapun teknik pengumpulan data yang dipergunakan dalam penelitan ini yaitu: Angket (kuesioner) ,Angket adalah lembaran pertanyaan yang dibagikan kepada siswa kelas V SDN147 Pekanbaru. Angket ini adalah angket tertutup dimana setiap item pertanyaan telah disediakan 5 buah alternatife jawaban (option) yaitu a, b, c, d dan e, untuk kepentingan analisa setiap alternatife jawaban, di beri bobot, alternatife jawaban a yang menggambarkan intensitas penggunaan Internet yang sangat aktif diberi bobot 5, alternatife jawaban b yang menggambarkan intensitas penggunaan Internet yang aktif diberi bobot 4,alternatife jawaban c yang menggambarkan intensitas penggunaan Internet yang cukup aktif diberi bobot 3, alternatife jawaban d yang menggambarkan intensitas penggunaan Internet yang kurang aktif diberi bobot 2, alternatife jawaban e yang menggambarkan intensitas penggunaan Internet yang tidak aktif diberi bobot 1, yang bertujuan untuk memperoleh data mengenai Pengaruh penggunaan teknologi terhadap akhlak. Dokumentasi ,Teknik dokumentasi ini dipergunakan untuk memperoleh data dari pihak sekolah mengenai data-data tentang deskriptif lokasi sekolah.

Teknik Analisis Data, Berdasarkan penelitian dan untuk menegetahui ada tidaknya penegaruh penggunaan Teknologi Informasi terhadap akhlak siswa maka data yang ada akan diolah da dianalisa menggunakan pendekatan kuntitatif dengan menggunakan nalisa regresi linier dengan Metode Kuadrat Terkecil.

$$
\dot{Y}=\mathrm{a}+\mathrm{bX}
$$

Dimana :

Ý $\quad=$ Akhlak

a $\quad=$ Konstana Intersepsi

$\mathrm{b} \quad=$ Koefisien

$\mathrm{X} \quad=$ Pengguaan Teknologi Informasi

Dengan kata lain model regresi dapat dipakai untuk meramalkan pengaruh Penggunaan Teknologi Informasi terhadap akhlak siswa. Hal ini mensyratkan bahwa untuk mencari signifikan korelasi antara kedua variable bias menggunakan rumus Korelasi Product Moment. Rumus yang digunakan: 
Keterangan:

rxy = Angka Indeks Korelasi "r" Product moment

$\mathrm{n} \quad=$ Sampel

$\Sigma \mathrm{XY}=$ Jumlah hasil perkalian antara skor $\mathrm{X}$ dan skor $\mathrm{Y}$

$\Sigma \mathrm{X}=$ Jumlah seluruh skor $\mathrm{X}$

$\Sigma \mathrm{Y} \quad=$ Jumlah seluruh skor $\mathrm{Y}$

Selanjutnya untuk menafsirkan besarnya koefisie korelasi degan cara kasar atau sederhana, berdasarkan criteria sebagai berikut :

Tabel.1 Interprestasi koefisien korelasi

Product moment

\begin{tabular}{|c|c|c|}
\hline $\begin{array}{l}\text { Besarnya } \\
\text { Moment }\end{array}$ & "r" Product & Interprestasi \\
\hline & $0,00-0,200$ & $\begin{array}{l}\text { korelasi antara variable } \mathrm{X} \text { dengan varabel } \mathrm{Y} \\
\text { sanagat lemah/ rendah sehingga dianggap tidak } \\
\text { ada korelasi }\end{array}$ \\
\hline & $0,200-0,400$ & korelasinya lemah atau rendah \\
\hline & $0,400-0,700$ & korelasi sedang atau kuat \\
\hline & $0,700-0,900$ & korelasi kulat ataul tinori \\
\hline & $0,900-0,1000$ & korelasi sangat kuat atau sangat tinggi \\
\hline
\end{tabular}

Menghitung besartnya sumbagan varabel $\mathrm{X}$ terhadap varabel $\mathrm{Y}$ dengan rumus

$\mathrm{KD}=\mathrm{R} 2 \mathrm{X} 100 \% 27$

Dimana;

$\mathrm{KD}=$ Koefisien Determinasi $/$ Koefisien Penentu

$\mathrm{R} 2=\mathrm{R}$ Square

Dalam proses data, penulis menggunakan bantuan peragkata computer melalui program SPSS (Statistical Program Society Science ) versi 18.0 for Windows. SPSS merupakan program salah satu paket program computer yang digunakan dalam mengolah data satistik.

\section{HASIL DAN PEMBAHASAN}

\section{Hasil Penelitian}

\section{Hasil Penelitian}

\section{Uji Linearitas}

Pengujian lenearitas dilakukan untuk melihat apakah masing-masing data variabel penggunaan Teknologi Informasi cenderung membentuk distribusi garis linear terhadap Akhlak siswa. Untuk mengetahui apakah persamaan regesi antara masing-masing variabel bebas $(\mathrm{X})$ bersifat linear atau tidak. Hasil pengujian linearitas tersebut ditunjukkan pada tabel 20 dan untuk analisa pengujian pada lampiran 9. 
Tabel 2. Linearitas Garis Regresi Akhlak (Y) Terhadap

Penggunaan Teknologi Informasi (X).

\begin{tabular}{|c|c|c|c|c|c|}
\hline \multicolumn{6}{|c|}{ ANOVA $^{\mathrm{b}}$} \\
\hline & Model & Sum of Squares & $\mathrm{df}$ & Mean Square F & Sig. \\
\hline \multirow[t]{3}{*}{$\overline{1}$} & Regression & 449.831 & 1 & 449.831 & $000^{\mathrm{a}}$ \\
\hline & Residual & 263.140 & 33 & 7.974 & \\
\hline & Total & 712.971 & 34 & & \\
\hline
\end{tabular}

a. Predictors: (Constant), Akhlak Siswa

b. Dependent Variable: Teknologi Informasi

Dari tabel 16 di atas, dapat diketahui Fhitung sebesar 56,413dengan tingkat probolitas 0,000 . Oleh karena probolitas $0,000<0,05$ maka distribusi data yang diteliti mengikuti bentuk linear (Ho ditolak, Ha diterima). Dengan kata lain model regresi dapat dipakai untuk meramalkan pengaruh teknologi informasi terhadap akhlak siswa. Hal ini mengisyaratkan bahwa untuk mencari signifikan korelasi antara kedua variabel bisa menggunakan rumus Korelasi Product Momont. Dengan demikian maka data dapat disimpulkan bahwa metode regresi Y terhadap X Berpola Linier

Selanjutnya untuk menguji persamaan linieritas dapat diperoleh data sebagai berikut :

\section{Tabel 3. Koefisien regresi linear}

\section{Coefficients $^{\mathrm{a}}$}

\begin{tabular}{llllll}
\hline Model & \multicolumn{2}{l}{$\begin{array}{l}\text { Unstandardized } \\
\text { Coefficients }\end{array}$} & \multicolumn{2}{l}{$\begin{array}{l}\text { Standardized } \\
\text { Coefficients }\end{array}$} \\
\cline { 2 - 4 } & $\mathrm{B}$ & Std. Error & Beta & $\mathrm{T}$ & Sig. \\
(Constant) & 7.152 & 5.477 & & 1.306 & .201 \\
Akhlak Siswa & 1.114 & .148 & .794 & 7.511 & .000 \\
\hline
\end{tabular}

a. Dependent Variable: Teknologi Informasi

Berdasarkan hasil analisis diperoleh persamaan regresi linear sebesar $\mathrm{Y}=7.152+1.114 \mathrm{X}$. Artinya setiap terjadi penambahan satu-satuan pada variabel $\mathrm{X}$ (teknologi informasi terhadap akhlak siswa), maka terjadi kenaikan pada variabel Y (akhlak siswa) sebesar 1.114.

Pengujian Hipotesis

Untuk melakukan pengujian hipotesis, digunakan uji statistik dengan teknik analisa Pearson Product Moment. Hipotesis yang diajukan dalam penelitian ini adalah Penggunaan Teknologi Informasi berhubungan terhadap Akhlak siswa. Pengujian hipotesis ini dilakukan unttuk mengetahui ada tidaknya hubungan variabel teknologi informasi $(\mathrm{X})$ terhadap akhlak siswa $(\mathrm{Y})$. Untuk meengetahui hubungan ini digunakan analisa korelasi Person product Moment.

Pengujian hipotesis dilakukan dengan rumusan hipotesis sebagai berikut :

Ha: Terdapat pengaruh teknologi informasi terhadap akhlak siswa kelas VSDN 147 Pekanbaru Kecamtan Tampan

Ho: Tidak terdapat pengaruh teknologi informasi terhadap akhlak siswa kelas VSDN 147 Pekanbaru Kecamtan Tampan 
Untuk memperoleh nilai $\mathrm{r}$ atau korelasi antara variabel $\mathrm{X}$ dan variabel $\mathrm{Y}$ dapat dilihat melalui program computer SPSS for Windows versi 18.0 sebagai berikut :

\section{Tabel 4. Korelasi Pearson}

\section{Correlations $^{\mathrm{a}}$}

\begin{tabular}{llll}
\hline & & \multicolumn{1}{c}{$\begin{array}{c}\text { teknologi } \\
\text { informasi }\end{array}$} & akhlak siswa \\
\hline teknologi informasi & Pearson Correlation 1 & $.815^{* *}$ \\
& Sig. (2-tailed) & .000 \\
akhlak siswa & Pearson Correlation & $.815^{* *}$ & 1 \\
& Sig. (2-tailed) & .000 & \\
**. Correlation is significant at the 0.01 level (2-tailed). \\
a. Listwise N=35
\end{tabular}

Berdasarkan hasil perhitungan diperoleh $\mathrm{r}$ (Pearson Correlation) 0.815 dengan tingkat probabilitas 0.000 . Oleh karena probabilitas lebih kecil dari 0,05 maka Ho ditolak, artinya ada pengaruh antara teknologi informasi dengan akhlak siswa kelas VSDN 147 Pekanbaru Kecamatan Tampan.

Tabel 5. Model Summary

\begin{tabular}{lllll}
\hline Model & & & & \multicolumn{2}{l}{ Std. Error of the } \\
& $\mathrm{R}$ & R Square & Adjusted R Square & Estimate \\
\hline $794^{\mathrm{a}}$ & .631 & .620 & 2.82382
\end{tabular}

a. Predictors: (Constant), Akhlak Siswa

b. Dependen Variabel , Teknologi Informasi

Berdasarkan hasil pengolahan data diatas dapat diketahui besarnya koefisien teknologi informasi terhadap akhlak siswa kelas VSDN 147 Pekanbaru Kecamtan Tampan adalah sebesar 0,794. Dari hasil analisis tersebut dapat diketahui bahwa :Tingkat pengaruh antara kedua variabel berada pada kategori kuat atau tinggi dengan reng $(0,700-0,900)$, yaitu sebesar 0,794.Koefisien determinasi (R-Square) adalah 0,631. Kontribusi teknologi informasi terhadap akhlak siswa sebesar $0,631 \times 100 \%=63,1 \%$ dan selebihnya dipengaruhi oleh faktor lainnya

\section{Hasil}

Hasil penelitian tentang deskripsi data dan klasifikasi data responden dalam setiap variabel yang diperoleh, bahwa hubungan antara teknologi informasi terhadap akhlak siswa kelas VSDN 147 Pekanbaru Kecamtan Tampanmasuk dalam kategori tinggi yaitu sebesar 63,1\%. Sedangkan dalam pengujian hipotesis yang diperoleh berdasarkan analisa data menunjukkan bahwa hubungan teknologi informasi terhadap akhlak siswa kelas V SDN 147 Pekanbaru Kecamatan Tampan sebesar $63,1 \%$, sedangkan 36,9\% berasal dari faktor lain yang tidak diteliti dalam penelitian ini.

Hasil penelitian yang mencakup uji homogenitas populasi dan hasil belajar siswa. Perbedaan hasil belajar siswa yang menggunakan permainan produksi kapal dan yang menggunakan metode konvensional. 


\section{KESIMPULAN}

Setelah penulis menyajikan data yang diperoleh melalui angket dan kemudian di analisis maka di jawab permasalahan yang penulis rumuskan pada bab terdahulu ada pengaruh antara dua variable yaitu berdasarkan data di atas dapat disimpulkan "Terdapat Pengaruh Teknologi Informasi terhadap akhlak siswa kelas V SDN 147 Pekanbaru Kecamatan Tampan, dapat diterima dengan sendirinya Ho di tolak ". Dengan kata lain semakin sering siswa menggunakan Teknologi Informasi maka akhlak siswa semakin buruk.

Bahwasanya penggunakan Teknologi Infromasi berpengaruh signifikan terhadap akhlak siswa kelas V SDN 147 Pekanbaru Kecamatan Tampan. Berdasrkan hasil perhitungan, uji Linieritas diperoleh $\mathrm{F}$ hitung $=56,413$ dengan tingkat probabilitas 0,000 . oleh karena probabilitas $0,000<0,05$ maka ditribusi yang diteliti mengikuti bentuk linier (Ho ditolak, Ha diterima). Dengan kata lain tingkat pengaruh antara dua variable berada pada kategori kuat atau tinggi $(0,700-0,900)$, yaitu sebesar 0.794

Berdasarkan hasil analisi diperoleh persamaan regresi linier yaitu $\mathrm{Y}=7,152+$ 1.114X. artinya setiap terjadi penambahan satu-satuan pada variable X ( Penggunaan Teknologi Informasi terhadap akhlak siswa ) maka terjadi kenaikan pada variable Y ( akhalk siswa ) sebesar 1.114

\section{REFERENSI}

Ali DR. Abdul Ali Halim. 2004. AkhlakMulia.Jakarta; GemaInsani

Asmaran, Dr. AS. 1992. PengantarStudi Akhlak.Jakarta: LembagaStudi Islam danKemayarakatan

AMuis. 2001.Indonesia di Era Dunia Maya.Bandung: PT RemajaRosdakarya

Darajat. Dr. Zakiah 1976.Membina Nilai-Nilai Moral di Indonesia.Jakarta: Bulan Bintang

Hariningsi SP. 2005. Teknologi Informasi. Yokyakarta: GrahaIlmu.

Hartono. 2008.StatistikUntukPenelitian. EdisiRevisiPekanbaru: Zanafa Publishing

Jalaluddin. 2007.Psikologi Agama. Jakarta; PT Raja GrafindoPersada

Kadir Abdul dan Triwahyuni Terra Ch. 2003.PengenalanTeknologiInformasi.Yokyakarta: AndiYokyakarta

Musthafa Drs. 2008. AkhlakTasawuf.Bandung: CV. PustakaSetia

Mukharuddin, 2011, Efektivitas Penggunaan media Pembelajaran (Internet) dalam Pembelajaran Muhaddasah di Pondok Pes.At-Taufiq Al-Islami Petapahan Tapung Kampar, UIN SUSKA RIAU,Tarbiyah dan Keguruan.Pendidikan Bahasa Arab

Nata Abuddin M.A. 2002. AkhlakTasawuf.Jakarta : PT RajaGrafindoPersada

Nursalim A.R. 2011. TeknikPenulisanKaryaIlmiah. Pekanbaru:Zanafa Publishing

Rachman fauzi m. 2009.Anakku KuantarkanKauke Surga.Jakarta: mizania

Raharjo Budi.2002. Memahami Teknologi Informasi.Jakarta: PT Gramedia

Simarmata Janner. 2005. PengenalanTeknologiKomputerdan Informasi.Yokyakarta: AndiYokyakarta 
Sudarsono. 1993.EtikaIsalamtentangKenakalanRemaja.Jakarta:RinekaCipta

Sugiyono Prof. Dr. 2009.MetodePenelitianPendidikan.EdisiRevisi Bandung: CV Alafabeta

Sumarni, 2011, Pengaruh media Internet di Sekolah terhadap Minat belajar siswa pada mata pelajaranekonomi kelas XI jurusan Ilmu Pengethuan sosial SMAN 1 Bangkinang Kabupaten Kampar, UIN SUSKA RIAU, Tarbiyah dan Keguruan, Pendidikan Ekonomi

Tohirin Drs. 2007. BimbingandanKonseling di Sekolahdan Madrasah.,Jakarta: PT RajaGrafindoPersada.

Tim Penyususnan Pembinaan dan Pengembangan Bahasa. 1990. Kamus Besar Bahasa Indonesia, Jakarta: Dinas Pendidikan Nasional

Muhammad Tholhah Hasan. 2004. Islam danMasalahSumberDayaAlam.Jakarta Selatan:Lantabora Press

UmaryBarmawie. Drs. 1993.MateriAkhlak, Solo, Ramadhani

Zahruddin AR.M.Si.dan Sinaga Hasanuddin. S.Ag.,M.A 2004. PengantarStudiAkhlak Jakarta: PT Raja GrafindoPersada

Wahid Fathul. 2001. KamusIstilahTeknologiInformasi.Yokyakarta:AndiYokyakarta

Winda Yuliana, 2011, Pengaruh Pemanfaatan Internet terhadap prestasi belajar pada mata pelajaran Ilmu Pengetahuan Ssosial di Sekolah Menengah Pertama Negri 4 Kecamatan Tambang Kabupten Kampar, UIN SUSKA RIAU, Tarbiyah dan Keguruan, Pendidikan Ekonomi. 